\title{
Solid pseudopapillary tumors of the pancreas: diagnosis and curative treatment
}

\author{
R. Frago, J. Fabregat, R. Jorba, F. García-Borobia, J. Altet, M. T. Serrano ${ }^{1}$ and C. Valls ${ }^{2}$ \\ Unit of Biliary-Pancreatic Surgery. Department of General and Digestive Surgery. Departments of ${ }^{\prime}$ Pathology and \\ ${ }^{2}$ Radio-Diagnosis. University Hospital of Bellvitge. L'Hospitalet de Llobregat. Barcelona, Spain
}

\begin{abstract}
Objectives: to highlight an infrequent occurrence using a series of clinical cases with symptoms and signs, and specific radiological findings allowing its diagnosis and treatment, which is in most cases successful.

Patients and methods: a descriptive and retrospective study of patients diagnosed by computed tomography scanning and then treated with surgery in the Pancreas and Biliary Unit of a University Hospital from March 1999 to September 2005.

Results: there were 6 female patients with a mean age of 33.5 years (range 11-72). Most common signs included pain and a palpable mass in the abdomen. Three patients were diagnosed by computed tomography scanning, and a differential diagnosis with a neuroendocrine tumor was performed for the remaining three subjects. Surgical treatment was adapted to each patient according to the findings and images seen in their computed tomography scans. Biopsy results confirmed the presumed diagnoses, and showed one case of solid pseudopapillary carcinoma of the pancreas. Average hospital stay was of 18.16 days (range 8-30). Mortality rate was $0 \%$. No recurrences occurred during follow-up for 46.3 months on average (range 12-76).

Conclusions: the presence of a huge mass in the pancreas of a young female should prompt suspicion for a solid pseudopapillary tumor. Given its low malignant potential, and the presence of specific radiographic patterns, its diagnosis should be accurate, as radical surgical treatment is effective.
\end{abstract}

Key words: Solid pseudopapillary tumor. Pancreas. Pancreatic neoplasms.

Frago R, Fabregat J, Jorba R, García-Borobia F, Altet J, Serrano MT, Valls C. Solid pseudopapillary tumors of the pancreas: diagnosis and curative treatment. Rev Esp Enferm Dig 2006; 98: 809-816.

Recibido: 15-11-05

Aceptado: 07-09-06.

Correspondencia: Ricardo Frago Montanuy. C/ Manuel de Falla, 28, $2^{\circ}-4^{\mathrm{a}}$. 08034 Barcelona. e-mail: 33055jfm@comb.es

\section{INTRODUCTION}

Solid pseudopapillary tumor of the pancreas (SPTP) is one of the less frequently found primary tumors of the pancreas, approximately in $0.17-2.7 \%$ of cases $(1,2)$.

Over the years it has been given several different names according to its macroscopic and microscopic pathological characteristics (papillary-cystic tumor, solid cystic tumor, papillary epithelial neoplasm, solid and papillary neoplasm, papillary tumor of the pancreas, or Frantz's tumor) until a consensus was reached in 1996, when it was defined by the World Health Organization (WHO) as a unique tumor with its current name: solid pseudopapillary tumor of the pancreas (3).

One of its characteristics is that it affects mainly young women (4). Most common symptoms are nonspecific abdominal pain together with bloating or a palpable abdominal mass. Occasionally the diagnosis is casually reached whilst doing other complementary tests -for example, ultrasounds or CT scan- for another condition.

It is a tumor that, despite possible histologic findings of malignancy, has a benign clinical behavior with low malignant potential (5). It also presents a specific immunohistochemical pattern, with findings in the macroscopic pathological analysis that correspond to images in the CT scan.

It is important to establish a precise preoperative diagnosis, given that radical surgery will usually be curative.

The aim of this publication is to highlight an unusual tumor, by means of a series of clinical cases, with a presentation of common symptoms and specific radiographic findings that allow preoperative diagnosis and then treatment, which will be curative in a majority of cases.

\section{MATERIAL AND METHODS}

A descriptive, retrospective study was carried out on six patients diagnosed with SPTP in an area of 
2,200,000 inhabitants from March 1999 to September 2005.

All patients were operated on in the Unit of BiliaryPancreatic Surgery a University Hospital.

All information was carefully recorded, including demographic characteristics, symptoms, diagnostic methods, pathologic correlation, surgical treatment, and morbidity and mortality rates.

The diagnostic method used was abdominal CT with an oral contrast and continuous intravenous contrast.

In all cases surgically removed pieces were fixed in 10\% formaldehyde and processed in paraffin. The diagnosis was confirmed by the histological analysis of these pieces.

Patient follow-up was performed on an outpatient basis following discharge from hospital.

\section{RESULTS}

During the period of this investigation -6 years- there were 6 cases of SPTP, five of which were young women, the other being a 72-year-old female. Mean age of the group was 33.5 years.

Symptoms were varied. Two patients were incidentally diagnosed when having an abdominal CT scan -one was being studied for arterial hypertension, the other had endometriosis and had at the time been admitted to hospital with acute pyelonephritis on the left side secondary to congenital renal atrophy. Three patients complained of pain and bloating for several months, and on physical exploration the presence of a palpable mass was noted. One 11-year-old patient who underwent appendectomy for her symptoms of acute appendicitis was found to have a perfectly normal appendix with a retroperitoneal hemorrhage, which led to complete her study during the postoperative period.
An initial diagnosis of SPTP was obtained before surgery using the evidence of symptoms and abdominal CT scans on all patients.

CT scans revealed a large hypervascular, encapsulated mass in contact with pancreatic tissues in all cases, with peripheral contrast enhancement and well defined margins. In three cases a mass with tissue heterogeneity and varying degrees of solid and cystic tissue was seen. In two cases the absence of the cystic component made it necessary to carry out a differential diagnosis between SPTP and neuroendocrine tumor of the pancreas (NETP); however, the fact that these were young female patients suggested an SPTP. In the 72-year-old patient the CT scan showed a large mass with solid and cystic components. The knowledge of cystic neuroendocrine tumors made differential diagnosis between SPTP and NETP a necessary step once again.

Radical surgical removal of the tumor was carried out in all patients. One patient who had a mass localized in the head of the pancreas underwent a cephalic pancreatic-duodenectomy with pyloric preservation and left nephrectomy. Another patient who had a tumor at the neck of the pancreas that extended to the superior part of the head and body of the gland underwent a distal pancreatectomy and partial resection of the head of the pancreas, with duodenal preservation, splenectomy, cholecystectomy, and hepatic jejunostomy ("Roux-en Y"). She needed a resection of the portal vein and reconstruction with autologous splenic vein due to the invasion of more than $50 \%$ of its circumference in the mesenteric-portal confluence. In the other four remaining cases the mass was located in the body and tail of the pancreas, and in these cases patients underwent distal pancreatectomy. Three of these four patients also underwent splenectomy (Table I).

The pathological study confirmed the suspected diagnosis of SPTP, and one case of solid pseudopapillary car-

Table I. Patient data and clinical information

\begin{tabular}{|c|c|c|c|c|c|c|c|c|}
\hline Case & Age (years) & $\begin{array}{l}\text { Clinical } \\
\text { presentation }\end{array}$ & Location & Size $(\mathrm{cm})$ & Cystic areas & CT diagnosis & Treatment & $\begin{array}{l}\text { Follow-up } \\
\text { (months) }\end{array}$ \\
\hline 1 & 32 & $\begin{array}{l}\text { Abdominal pain, } \\
\text { palpable mass }\end{array}$ & Neck-body & $7 \times 6$ & No & NETPs vs. SPTP & $D P+S^{* *}$ & 76 \\
\hline 2 & 23 & Incidentally found & Head & $6 \times 5.5$ & No & NETPs vs. SPTP & $\begin{array}{c}\text { CPD + } \\
\text { nephrectomy* }\end{array}$ & 61 \\
\hline 3 & 27 & $\begin{array}{l}\text { Abdominal pain, } \\
\text { palpable mass }\end{array}$ & Neck-body & $16 \times 14$ & Yes & SPTP & $D P+S$ & 55 \\
\hline 4 & 11 & Abdominal pain & Head-neck & $6 \times 1.7$ & Yes & SPTP & DP & 42 \\
\hline 5 & 36 & Incidentally found & Body & $3.7 \times 2.8$ & Yes & SPTP & $D P+S$ & 32 \\
\hline 6 & 72 & $\begin{array}{l}\text { Abdominal pain, } \\
\text { palpable mass }\end{array}$ & Body-tail & $7.3 \times 5.4$ & Yes & NETPs vs. SPTP & $D P+S$ & 12 \\
\hline
\end{tabular}

SPTP: solid pseudopapillary tumor of the pancreas; NETP: neuroendocrine tumor of the pancreas; CPD: cephalic duodenopancreatectomy; DP: distal pancreatectomy; S: splenectomy; vs.: versus

*With pyloric preservation.

**Partial resection of the head of the pancreas with duodenal preservation, splenectomy, cholecystectomy, and hepatic jejunostomy ("Roux-en Y"), with resection of the portal vein and reconstruction with autologous splenic vein. 
cinoma of the pancreas due to the invasion of the portal vein was reported.

With regard to morbidity rate, one case of biliary fistula, and one of pancreatic fistula, both of little importance, were treated and cured without surgery. Average hospital stay was 18.16 days (range: 8 to 30 ). Mortality rate was $0 \%$. No recurrence was seen during postoperative follow-up for 46.3 months on average (range 12 to 76 ); interestingly, the only case of solid pseudopapillary carcinoma of the pancreas was also the patient with the longest follow-up.

\section{DISCUSSION}

The increasing interest in pancreatic conditions over the last few years, and the more detailed knowledge of some illnesses, has favored an increase in the number of cases diagnosed with SPTP. This is probably due to a better understanding of this tumor, rather than an actual increase in the number of cases, given the microscopic resemblance between this tumor and islet cell tumors (6).

This is a non-secreting tumor that primarily affects young women $(91 \%)$. Mean age at diagnosis is between 23.9 and 25.5 years in women $(7,8)$, and 31.4 years in men (8). In patients younger than 15 years there does not appear to be a greater incidence in females, as opposed to adults $(9,10)$. There is still controversy regarding the origin of this tumor. It was thought to be related to genetic factors, as there was a higher incidence amongst Asian women (10). Dependence on sexual hormones has also been suggested $(7,8)$. In the report by Mao et al., upon studying hormone receptors, 9 out of 46 cases tested positive for PGR (progesterone receptor) $(11,12)$, whilst Koshmal et al. found that $100 \%$ of 57 cases tested positive for PGR (13). On observing such disparate results it is believed that sexual hormones play a more important role in this tumor's growth rather than origin $(4,12,14)$. Koshmal et al. have also suggested that the origin of this tumor may be outside the pancreas, and located it at the gonadal level. Currently, the most accepted theory is that of its origin in a pluripotential cell capable of differentiation in an exocrine or endocrine sense (15-17), which would occur during infancy and then grow over the years (18).

Most frequent symptoms include abdominal discomfort, on occasions associated with a palpable abdominal mass (19-21). It is not unusual that a diagnosis is incidentally arrived at during a study carried out for another cause or abdominal trauma (22-25). Even more unusual is its presentation as an acute abdomen syndrome, with the patient developing hemoperitoneum from spontaneous rupture or intratumoral bleeding $(7,21,26)$. A cholestatic syndrome from bile duct compression is also uncommon. There are usually no signs of pancreatic insufficiency, either endocrine or exocrine, nor elevated transaminases, amylases, or tumor markers such as CEA and CA 19.9.
These are solid tumors in which sclerosis develops along their vascular stalk. This results in ischemia, with bleeding in distal tissue and a possibility for cystic areas developing within the tumor. The area between the solid and cystic tissue components has a pseudo-papillary appearance. This histological evolution of the tumor may be seen in radiographic findings.

The imaging technique most widely used in its diagnosis is CT scanning (27-29), and there is a characteristic -though nonspecific- pattern. In radiographic studies, the presence of a large hypervascular encapsulated mass is noted in contact with the pancreatic tissue, with peripheral contrast enhancement. It may show either a solid or cystic aspect, or be heterogeneous in appearance (Fig. 1). The existence of various layers of cystic tissue (Fig. 2) will correspond to the solid tissue necrosis found in the pathologic study (Fig. 3). Occasionally, calcifications and bleeding signs may be seen inside the tumor. Differentiating SPTPs from adenocarcinomas is crucial, as the latter's prognosis is much worse (30). MRI images show characteristics similar to those of CT, enabling a clearer picture of bleeding areas (29). Currently there is an increased use of echo-endoscopy with fine-needle puncturing in the diagnosis of this pancreatic neoplasm, which are especially useful for cystic lesions (4). On certain occasions this may help in the study of the tumor (31).

An assessment of epidemiological data, symptoms, and radiographic findings allows its differential diagnosis with other tumors, especially with the NETP (32). NETP, as is also the case with pancreatic adenocarcinoma, will rarely include a cystic component. The latter also predominantly involves older people, and will usually not reach such a large size.

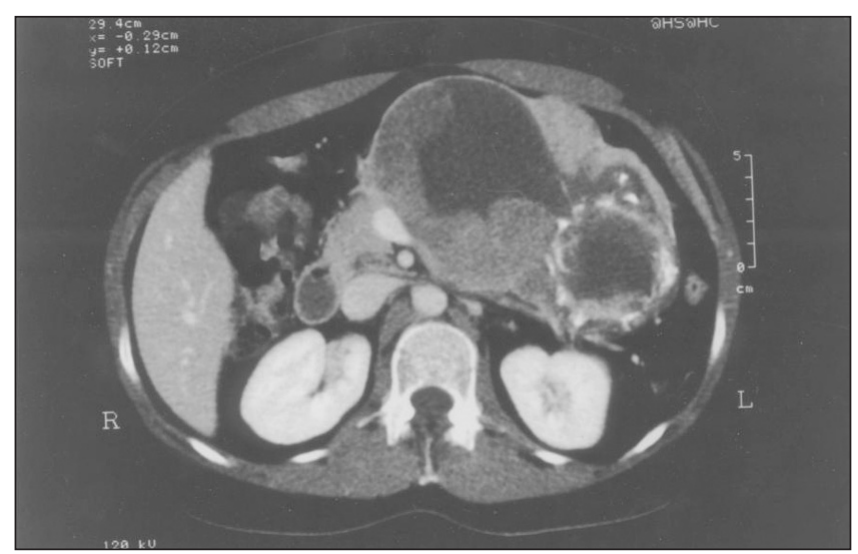

Fig. 1.- The tumor is located in the body-tail section of the pancreatic gland, is $16 \times 14 \times 11 \mathrm{~cm}$ in diameter, encapsulated, with solid and cystic areas, and rejects adjacent tissues without infiltration. The proximal area is mainly solid. The area corresponding to the tail of the pancreatic gland is cystic, with calcifications in the wall.

Tumoración localizada en cuerpo-cola de páncreas, de $16 \times 14 \times 11 \mathrm{~cm}$ de diámetro, de aspecto encapsulado, con áreas sólidas y quísticas, que rechaza estructuras adyacentes sin infiltración. La zona proximal de predominio sólido con zonas de menor atenuación que corresponden a líquido. La zona correspondiente a la cola, de características quísticas presenta calcificaciones en su pared. 


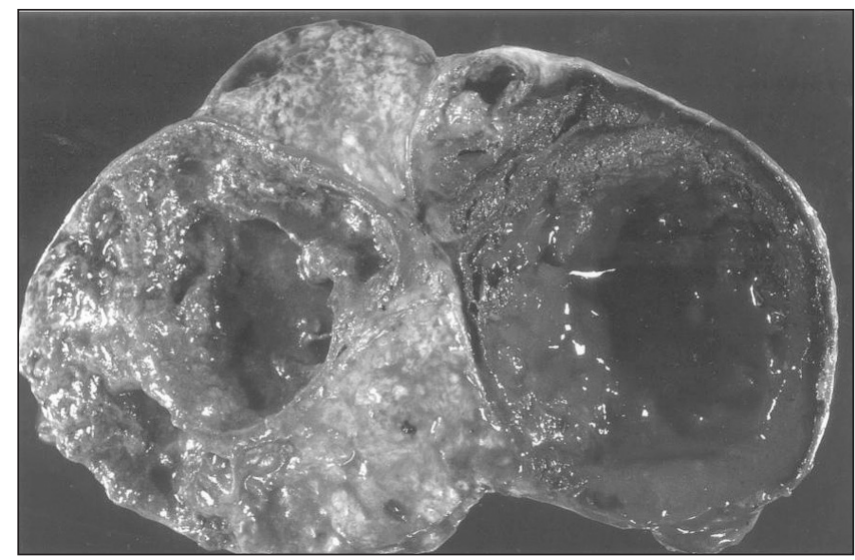

Fig. 2.- Lesion comprising both solid and cystic areas. Some of the cystic areas display hemorraghic content and the wall is partially calcified, while other show necrosis or granular or papillary formations. Solid areas have a homogeneous appearance, but may display microcysts.

Lesión constituida por áreas quísticas y áreas sólidas. Algunas de las áreas quísticas muestran un contenido hemorrágico y su pared está parcialmente calcificada, otras muestran contenido necrótico y otras un contenido granular o papilar. Las áreas sólidas son de aspecto homogéneo aunque focalmente muestran un aspecto microquístico.

This tumor can be very large. Location in the pancreatic gland is variable, although in $64 \%$ of all cases it is found in the body and the tail of the pancreas (4). It can displace nearby organs, and on rare occasions infiltrate them. Even though distant metastases have been found, this is a rare occurrence $(5,33-35)$.

Once the suspected diagnosis has been established, and given a good biological reaction independently of patient age, it is believed that radical tumor surgery by a specialized pancreatic surgery team can be curative (36), even in the presence of metastatic disease or recurrence. Neither extensive lymphatic dissection nor adjacent structure resection are warranted $(2,30,32,35,37)$. Patients treated with local resection involving the tumor alone, without excising any surrounding tissue, have a higher rate of recurrence (18).

Malignancy is determined by vascular and nervous invasion, and the presence of lymph node or liver metastases, which in these cases define the lesion as a solid pseudo-papillary carcinoma (3).

The roles of chemotherapy and radiotherapy are unclear, although experimental chemotherapy with IPE (iphosphamide, cisplatin, etoposide) has been used in cases of liver metastasis (23).

We can conclude that the presence of a large mass in the pancreas of a young woman may suggest SPTP. This growth has a low potential for malignancy and an excellent prognosis with specific radiographic patterns. Finally, its diagnosis should be accurate given that radical surgical treatment can be curative.

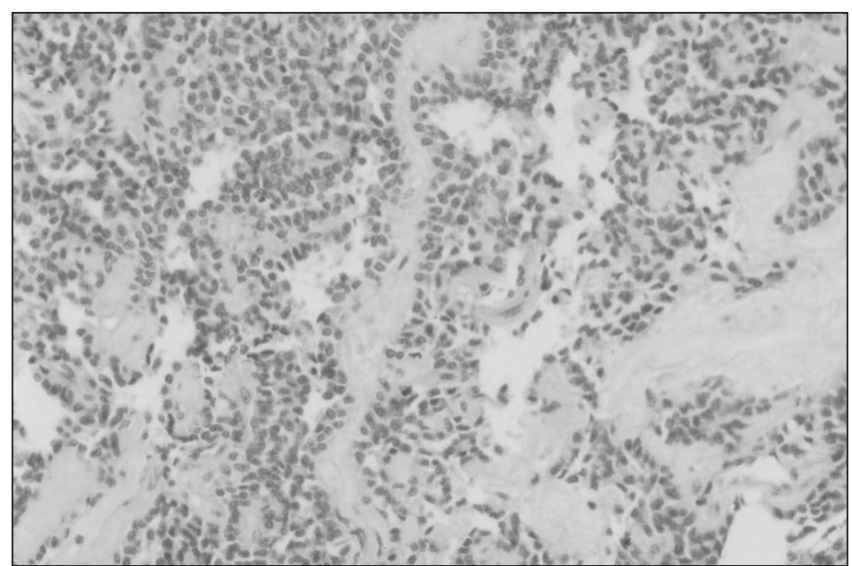

Fig. 3.- Constant cell proliferation and concomitant desquamation giveing to the tumor a pseudopapillary appearance around its fibrovascular stalk. No mitoses or atypical cells were found.

Prolifefación celular monótona con dehiscencia de las células que provoca un aspecto pseudopapilar con un eje central fibroesclerótico. Las células no muestran atipia ni se identifican mitosis.

\section{REFERENCES}

1. Cubilla AL, Fitzgerald PJ. Cancer (non-endocrine) of the pancreas: A suggested classification. Monogr Pathol 1980; 21: 82-110.

2. Morohshi T, Held G, Kloppel G. Exocrine pancreatic tumours and their histological classification: A study based on 167 autopsy and 97 surgical cases. Histopathology 1983; 7: 645-61.

3. Kloppel G, Solcia E. Longnecker DS, Capella C, Sobin LH. World Health Organization institutional histological classification of tumours-histological typing of tmours of the exocrine pancreas. 2nd ed. Berlin, Germany: Springer-Verlag, 1996.

4. Rebhandl W, Felberbauer FX, Puig S, Paya K, Hochschorner S, Barlan M, et al. Solid-pseudopapillary tumor of the pancreas (Frantz tumor) in children: report of four cases and review of the literature. J Surg Oncol 2001; 76 (4): 289-96.

5. Yamanue H, Tanimura H, Shono Y, Onishi H, Tani M, Yamoto H, et al. Solid and cystic tumor of the pancreas: clinicopathologic and genetic studies of four cases. Int J Pancreatol 2000; 27 (1): 69-76.

6. Zinner MJ. Solid and papillary epithelial neoplasms of the pancreas. Surg Clin Noth Am 1995; 75 (5): 1017-24.

7. Mao C, Guvendi M, Domenico DR, Klim K, Thomford NR, Howard JM. Papillary cystic and solid tumors of the pancreas: a pancreatic embryonic tumor? Studies of three cases and a cumulative review of the world's literature. Surgery 1995; 118 (5): 821-8.

8. Nishihara K, Tsuneyoshi M, Ohshima A, Yamaguchi K. Papillary cystic tumor of the pancreas: is it a hormone dependent neoplasm? Pathol Res Pract 1993; 189 (5): 521-6.

9. Lee WJ, Park YT, Choi JS, Chi HS, Kim BR. Solid and papillary neoplasms of the pancreas. Yonsei Med J 1996; 37 (2): 131-41.

10. Jung SE, Kim DY, Park KW, Lee SC, Jang JJ, Kim WK. Solid and papillary epithelial neoplasm of the pancreas in children. World $\mathrm{J}$ Surg 1999; 23 (3): 233-6.

11. Ladanyi M, Mulay S, Arseneau J, Bettez P. Estrogen and progesterone receptor determination in the papillary cystic neoplasm of the pancreas. With immunohistochemical and ultrastructural observations. Cancer 1987; 60 (7): 1604-11.

12. Sclafani LM, Reuter VE, Coit DG, Brenann MF. The malignant nature of papillary and cystic neoplasm of the páncreas. Cancer 1991; 68 (1): $153-8$.

13. Kosmahl M, Seada LS, Janiq U, Harms D, Kloppl G. Solid-pseudopapillary tumor of the páncreas: its origin revisited. Virchows Arch 2000; 436 (5): 473-80. 
14. Morales A, Ruiz Molina JM, Esteves HO, Robles-Díaz G, Díaz-Sánchez V. Papillary-cystic neoplasm of the pancreas. A sex-steroid dependent tumor. Int J Pancratol 1998; 24 (3): 219-25.

15. Stommer P, Kraus J, Stolte M, Giedl J. Solid and cystic pancreatic tumors. Clinical, histochemical, and electron microscopic features in ten cases. Cancer 1991; 67 (6): 1635-41.

16. Ferlan-Marolt V, Pleskovic L, Pegan V. Solid papillary-cystic tumor of the pancreas. Hepatogastroenterology 1999; 46 (29): 2978-82.

17. Nishihara K, Nogoshi M, Tsuneyoshi M, Yamaguchi K, Havashi I. Papillary cystic tumors of the pancreas. Assessment of their malignant potential. Cancer 1993; 71 (1): 82-92. Review.

18. Wang KS, Albanese C, Dada F, Skarsgard ED. Papillary cystic neoplasm of the pancreas: a report of three pediatric cases and literature review. J Pediatr Surg 1998; 33 (6): 842-5.

19. Papavramidis T, Papavramidis S. Solid pseudopapillary tumors of the pancreas review of 718 patients reported in English literature. J Am Coll Surg 2005; 200 (6): 965-72.

20. Wunsch LP, Flemming P, Werner U, Gluer S, Burger D. Diagnosis and treatment of papillary cystic tumor of the pancreas in children. Eur J Pediatr Surg 1997; 7 (1): 45-7.

21. Panieri E, Krige JE, Bornman P, Graham SM, Terblanche J, Cruse JA. Operative management of papillary neoplasm of the pancreas. J Am Coll Surg 1998; 186 (3): 319-24.

22. Duff P, Greene VP. Pregnancy complicated by solid-papillary epithelial tumor of the pancreas, pulmonary embolism, and pulmonary embolectomy. Am J Obstet Gynecol 1985; 152 (1): 80-1.

23. Martin RC, Klimstra DS, Brennan MF, Conlon KC. Solid-pseudopapillary tumor of the pancreas: a surgical enigma? Ann Surg Oncol 2002; 9 (1): 35-40.

24. Ng KH, Tan PH, Thng CH, Ooi LL. Solid pseudopapillary tumour of the pancreas. ANZ J Surg 2003; 73 (6): 410-5.

25. Casanova M, Collini P, Ferrari A, Cecchetto G, Dall'Igna P, Mazzaferro V. Solid pseudopapillary tumor of the pancreas (Frantz tumor) in children. Med Pediatr Oncol 2003; 41 (1): 74-6.

26. Canzonieri V, Beretta M, Buonadonna A, Libra M, Vasquez E, Barbagallo E, et al. Solid pseudopapillary tumour of the páncreas. Lancet Oncol 2003; 4 (4): 255-6.

27. Yamaguchi K, Hirakata R, Kitamura K. Papillary cystic neoplasm of the pancreas: radiological and pathological characteristics in 11cases. Br J Surg. 1990; 77 (9): 1000-3.

28. Dong PR, Lu DS, Degregario F, Fell SC, Au A, Kadell BM. Solid and papillary neoplasm of the pancreas: radiological-pathological study of five cases and review of the literature. Clin Radiol 1996; 51 (10): 702-5.

29. Buetow PC, Buck JL, Pantongrag-Brown L, Beck KG, Ros PR, Adair CF. Solid and papillary neoplasm of the pancreas: imagingpathologic correlation in 56 cases. Radiology 1996; 199 (3): 707-11.

30. Yoon DY, Hines OJ, Bilchik AJ, Lewin K, Cortina G, Reber HA. Solid and papillary epithelial neoplasms of the pancreas: aggressive resection for cure. Am Surg 2001; 67 (12) : 1195-9.

31. Visser BC, Muthusamay VR, Mulvihill SJ, Coakley F. Diagnosis imaging of cystic pancreatic neoplasms. Surg Oncol 2004; 13 (1): 27-39. Review.

32. Alexandrescu DT, O'Boyle K, Feliz A, Fueg A, Wiemik PH. Metastatic solid-pseudopapillary tumor of the pancreas: clinico-biological correlates and management. Clin Oncol (R Coll Radiol) 2005; 17 (5): 358-63.

33. Horisawa M, Niinomi N, Sato T, Yokoi S, Oda K, Ichikawa M, et al. Frantz's tumor (solid and cystic tumor of the pancreas) with liver metastasis: successful treatment and long-term follow-up. J Pediatr Surg 1995; 30 (5): 724-6.

34. Klimstra D, Wenig BM, Heffess CS. Solid-pseudopapillary tumor of the pancreas: a typically cystic carcinoma of low malignant potential. Semin Diagn Pathol 2000; 17 (1): 66-80.

35. Washington K. Solid-pseudopapillary tumor of the pancreas: challenges presented by an unusual pancreatic neoplasm. Ann Surg Oncol 2002; 9 (1): 3-4.

36. Domínguez Comesaña W, Turégano Fuentes F, Sanz Sánchez M, Camacho Lozano A. Papillary-cystic carcinoma of he páncreas: an infrequent tumor sith favorable prognosis. Rev Esp Enferm Dig 1989; 76 (2): 185-7.

37. Iribarren Díaz M, de Castro Parga G, Fernández Martín R, Meléndez Villa R, Ferreira Barreiro, García Lorenzo F. Neoplasia epitelial pseudopapilar sólido-quistica de páncreas (tumor de Frantz). Estudio de dos nuevos casos. Rev Esp Enferm Ap Dig 2004; 96 (12): $877-8$ 